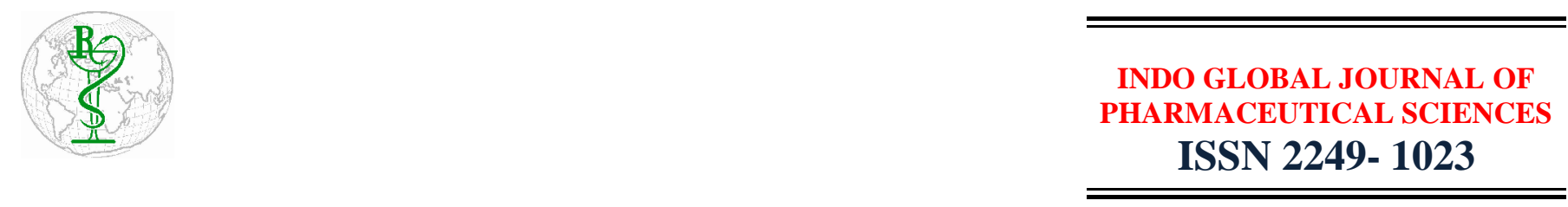

\title{
Enzyme \& Microbial Technology in Food Processing
}

\author{
Subhash Chand * \\ Department of Biochemical Engineering \& Biotechnology, Indian Institute of Technology Delhi, New Delhi-110016, India \\ Address for Correspondence: Subhash Chand; subhashc46@hotmail.com
}

\begin{abstract}
Food processing aims at extending the period during which a food remains wholesome or increasing the variety in the diet, while maintaining the nutritional and health care needs. The use of enzymes and microbes (being the natural biocatalysts; derived from living systems) has been a desirable choice in food processing, due to their ambient processing conditions. During the past three decades, the developments in bioprocessing tools and techniques have significantly expanded the potential for bulk enzyme applications e.g. production of bioactive peptides, oligosaccharides and lipids, besides the conventional industrial applications in food processing. Some of these developments include extended use of the biocatalysts (as immobilized enzymes), microbes (both natural and genetically modified) as sources for bulk enzymes and modification of enzyme properties through protein engineering. Similarly, the microbes have been the biological catalyst of choice for the production of a variety of fermented foods around the world. Their use for the manufacture of different additives used in food processing, e.g. thickeners, flavors, pigments and food preservatives has been an activity of commercial interest for a long time. The presentation would throw light on some of these potential applications to expand the base of food processing industry in India. (c) 2014 iGlobal Research and Publishing Foundation. All rights reserved.
\end{abstract}

Conference Proceedings: International Conference on Life Sciences, Informatics, Food and Environment; August 2930, 2014

Indo Global Journal of Pharmaceutical Sciences( ISSN 22491023 ; CODEN- IGJPAI; NLM ID: 101610675) indexed and abstracted in EMBASE(Elsevier), SCIRUS(Elsevier),CABI, CAB Abstracts, Chemical Abstract Services(CAS), American Chemical Society(ACS), Index Copernicus, EBSCO, DOAJ, Google Scholar and many more. For further details, visit 